\title{
DEMOCRACY, LOCAL ELECTION, AND POLITICAL DYNASTY IN INDONESIAN POLITICS
}

\author{
Dede Mariana dan Luthfi Hamzah Husin \\ Departemen Ilmu Politik Universitas Padjadjaran \\ E-mail: d.mariana@unpad.ac.id
}

\begin{abstract}
Liberal democracy has been chosen as a model and political mechanism after Soeharto era. One of its triumph is the rise of local election which becomes a political instrument of democratisation at regional level. Many scholars believe that local democratisation in Indonesia enables local people to involve more actively in the political process. This political exercise in some cases, however, created paradoxical impact on Indonesian political realm today, as some practices of political dynasty frequently emerge. Using participatory point of view, this article aims to discuss why the phenomena of political dynasty can possibly emerge within a local election, what factors are causing it to appear and how it affects the future of local democracy in Indonesia. Through the literature studies, we argue that although the liberal democratisation in Indonesia is successful in making local politics institutionally more democratic, it still suffers a lot of deficiencies and limitations especially in terms of accommodating the participation of local people.
\end{abstract}

Key words: democracy, participation, local election, political dynasty, Indonesia

\section{DEMOKRASI, PEMILIHAN KEPALA DAERAH, DAN DINASTI POLITIK DI INDONESIA}

\begin{abstract}
ABSTRAK
Demokrasi liberal telah dipilih sebagai sebuah model dan mekanisme politik pasca era-Soeharto. Satu di antara puncak capaiannya adalah kemunculan pemilihan kepala daerah yang menjadi sebuah instrument politik bagi proses demokratisasi pada tataran lokal. Banyak ilmuwan politik meyakini bahwa demokratisasi lokal di Indonesia memungkinkan masyarakat daerah untuk terlibat lebih aktif dalam proses politik. Akan tetapi, percobaan politik ini dalam berbagai kasus menghasilkan sebuah dampak paradoks pada dunia perpolitikan di Indonesia dewasa ini, di mana praktek politik dinasti marak bermunculan. Dengan menggunakan perspektif partisipatif, tulisan ini bertujuan untuk mendiskusikan mengapa politik dinasti tersebut bisa dimungkinkan untuk muncul di tengah-tengah sistem elektoral, apa saja faktor yang menyebabkan hal itu, dan bagaimana dampaknya pada praktik demokrasi di tataran lokal di Indonesia pada masa yang akan datang. Melalui studi literatur, kami berargumen bahwa meskipun demokratisasi liberal di Indonesia berhasil untuk membuat politik lokal lebih demokratis secara institusional, ia masih mengalami kekurangan dan keterbatasan khususnya dalam mengakomodasi partisipasi masyarakat lokal.
\end{abstract}

Kata kunci: demokrasi, partisipasi, pemilihan kepala daerah, politik dinasti, Indonesia

\section{PREFACE}

After nearly two decades of the fall of Soeharto, liberal democratisation in Indonesia has steadily proceeded. Some scholar, like Peou (2014: 39), argues that Indonesia's experience of democracy, although it has passed many political transitions and problems, shows a positive trend compared to other young democratic states, such as Thailand, Philippines, Myanmar, and Iraq. Indonesia has experienced improved performance in democracy which can be measured from the application of decentralisation and local autonomy, the emergence and the ability of political parties to freely compete within an electoral system, the participation of civil society in the political process by controlling the state, and the role of press media in the public sphere. Apart of the democratic euphoria, it can be said that the most significant triumph of democratisation in Indonesia now is the establishment of liberal democratic institutions and procedures as the only way to articulate common interests (Abdulbaki, 2008).

Such national political landscape is then followed by local democratisation agenda. Through the Local Government Act Number 32 Year 2004 that contains the principle of decentralisation, people are able to choose their 
leader at sub-national level by participating in direct elections. Political participation in local election, therefore, becomes a central issue as it determines the quality of local democracy. For developmentalist theory, like Lipset, people's participation in democracy is highly determined by the economic background they have, and accordingly democratisation is always hand in hand with development agenda (Tadjoeddin, 2012). This logic is based on the assumption that economic growth can automatically strengthen and improve participation in democratisation process. Furthermore, localdemocratisation goes hand in hand with the idea of good governance, which was introduced by World Bank in the late of twentieth century, as the central government can deliver power to local government in order to make efficient management by applying the principles of transparency, accountability, participation, and so on. Drawing on this theoretical framework, developmental theorists strongly believe that participatory problem we are facing now in Indonesia could be solved as the economic growth arises and the good governance principles are applied at local level.

Practically speaking, however, local election in Indonesia has caused some new problems. According to research conducted by Trajano and Yoes (2013), Indonesian local democracy in some cases tends to grow political dynasty that can obstruct the democratisation process. There is a tendency among local political actors to build their political dynasty and monopolise the electoral system by transferring power to their family members, for instance Atut Chosiyah's dynasty in Banten and Yasin Limpo's dynasty in South Sulawesi. Moreover, this kind of tendency is often related to corruptive behavior. In late 2016, there were two heads of local government arrested by Indonesian Commission for Corruption Eradication (Komisi Pemberantasan Korupsi or KPK). Atty Tochija, who was the Mayor of Cimahi at the time, and her husband, who was the previous two-period Mayor of Cimahi, were arrested (Sawitri, 2016). After a short time, Sri Hartini as the Regent of Klaten, whose husband was also the previous Regent of Klaten, was also arrested due to involvement in bribery case. (Artharini, 2017).

The practice of political dynasty is not only prone to corruption action, but also hijacks people's participation at the same time. As they build their kinship connection and maintain status quo, there is a necessity to perpetuate patron-client relation and monopolise the electoral system. According to Trajano and Yoes (2013: 2), the ultimate cause of political dynasty, especially in the young democratic state like Indonesia, is 'the weak political party institutionalisation.' Seen in this light, local political parties seem to be failed as they cannot aggregate their constituent's interest and nominate an alternative leader. A dynastic family, therefore, is enabled to occupy the structure of political party and undermine people's participation in political process. This is not surprising that political dynasty can possibly emerge, since political party is the main vehicle in liberal democracy.

Given the case of political dynasty above, it can be said that the implementation of liberal democracy in Indonesia suffers critical issues. Is liberal democratisation in local level sufficient to accommodate people's participation? If so, why does political dynasty frequently emerge within an electoral system? What are the factors that create the embodiment of political dynasty? Furthermore, what are political dynasty's implications to Indonesian's democracy and local election nowadays? In the following sections, the discussion here will be strongly related to those questions.

Using participatory democracy point of view, this article suggests two main arguments. Firstly, liberal democracy, especially in the contextoflocallevel,sufferslimitationasitcannot really overcome the political dynasty resulted by local elections. Thus, the modernisation and development agenda through decentralisation trajectory cannot necessarily improve people's participation at local level. Secondly, it is argued that liberal democratisation at local level is not entirely congruent with the local context, even in some ways, it becomes a new kind of political instrument to castrate people's participation.

\section{METHOD}

This study uses literature review as a method to explain the case of political dynasty in Indonesian local elections. We collect some theories, perspectives, and findings from literatures that are strongly related to the topic, such as peer-reviewed journal articles and main political theory books. In the 
analytical framework, we first begin the study by constructing the theoretical assumptions, especially from the theory of participation in democracy and of oligarchical democracy in young democratic state. These theoretical assumptions are important to guide the analysis of the phenomenon of political dynasty. Second, we then observe the phenomenon of political dynasty in Indonesian local election by searching some press' reports and literature's findings. As the focus of the study, our central point is the political dynamics of decentralisation and local autonomy in Indonesia after 2004.

\section{RESULT AND DISCUSSION}

\section{Participatory Problem In Indonesian Local Democracy}

Talking about the cause of political dynasty in a democratic system is not simply because of the weakness of liberal democratic institutions, as modernist theorists propose. It is not also simply caused by the low economic growth that local people have, as developmental theorists suggest. Rather, we argue that there is a paradigmatic fallacy in how we practice and apply liberal democracy in the context of Indonesian's experience. To develop this critique, it is important to firstly notice the work of Pateman, who emphasises Rousseau's classical theory of participation in democracy. As she notes in Participation and Democratic Theory (2014 [1970]: 22),

'Rousseau's political theory hinges on the individual participation of each citizen in political decision making and in his theory participation is very much more than a protective adjunct to a set of institutional arrangement; it also has a psychological effect on the participants, ensuring that there is a continuing interrelationship between the working of institutions and the psychological qualities and attitudes of individuals interacting with them.'

Participatory theory, according to Rousseau, criticises the concept of representation in democracy which merely depends on limited representative institutions. Vice versa, Rousseau emphasises individual's participation in political process regardless the differences existing in society. In the light of this perspective, therefore, local representative institutions, such as, local government, local election, and local political party, can be considered to be insufficient to accommodate people's participation as they delegate political mandate and decision-making process to certain actors or elites at the higher level of political institutions. By way of contrast, 'the theory of participatory democracy is built around the central assertion that individuals and their institutions cannot be considered in isolation from one another' (Pateman, 2014 [1970]: 42).

Accordingly, in the context of political dynasty, Schumpeterian model of democracy at local level can be easily misused by political elites because the political instrument institutionally separates people's direct participation with their institutions. This political landscape, hence, enables any dynastic family to emerge and utilise the electoral system in order to perpetuate their patronage linkage. As there is no political equality on every social element to equally participate in decision-making process, political elites which embodied in a dynastic family can easily manipulate the game of liberal democracy and monopolise it.

Strictly speaking, for participatory democratic point of view, the ultimate cause of why the political dynasty still emerges within a democratic society is the failure of liberal democratic arrangement to really accommodate people's participation in local democracy, and therefore, modernisation and development agenda, which are strongly promoted by liberal democrats, have been also proven to fail in regard of improving people's participation at local level. The paradigmatic fallacy here is not only found in the concept that liberal democrats impose, butalso in the existing liberal democratic institutions and procedures as the only way to articulate politics in local democracy. Hence, in the context of local election, there is no political guarantee that people's representatives in electoral system can necessarily represent their constituents and make a decision for the sake of them. People's participation cannot be simply reduced by solely depending on their involvement in local election and neglecting their direct participation and control outside 'proceduralism' horizon.

Moving beyond Rousseau's participation theory, we ought to consider Hirst's theory 
of associational democracy, who develops the concept of participatory democracy to be more realistic to be applied in modern society. For him, associational democracy 'always presupposed the plurality and autonomy of enterprises and collective bodies as decision-making agencies. It assumed a system of cooperatively and associativelyowned agencies that were to be managed by procedures which depended on democratic consent' (Hirst, 1988: 141). Borrowing his theory, therefore, we ought to reformulate Rousseau's necessity of individual-based participation to be more associational, as it can be more practical to control and prevent every dynastic or patrimonial potential and escape from the logic of individualism as the core value of liberal democracy.

Seen in this light, the concept of 'participation', which was perceived as merely a political procedure by voting and then nominating a representative, now turns to become more political. This kind of associational participation eventually enables to prevent the embodiment of political dynasty as they have to deal with the social control held genuinely by people. Every social association within local people can organise themselves and make an autonomous body 'to set their own objective' (Hirst, 1988: 142). To do this theory more practically, local democracy, including local electoral system, ought to be reformulated, so it will not be trapped in a narrow and limited representative institutions and enable to accommodate people's participation more widely.

\section{The Incongruity of Local Democratisation Agenda}

Although democratisation process at local level has been successful to make local politics more institutionally democratic, there is a profound tendency of political dynasty resulted by local elections as discussed in the previous sections. This political phenomenon, in some ways, can jeopardise the ongoing democratisation process at local level, while, at the same time, shows us the limitation and deficiency of liberal democratisation. Accordingly, some critical issues arise: why does the dream of liberal democratisation at local level eventually castrate people's participation and even enable a political dynasty to arise? Is then the idea of liberal democratisation in local democracy, as a single political articulation, necessarily congruent with the nature and the political reality of Indonesian politics? Drawing on the theoretical framework of participatory democracy, we strongly argue that the imposition of local democratisation agenda followed by the establishment of liberal democratic institutions is far from the ideal participatory condition, so it is arguably prone to abusive action, especially the practice of political dynasty. To scrutinise the argument more deeply, there are three main problems in Indonesian local politics that liberal democratisation cannot successfully overcome.

Firstly, Indonesian's experience of democratisation nowadays still has to deal with the problem of oligarchical culture. As the work of Fukuoka (2013: 52), which explores the oligarchy literature on Indonesian democratisation, notes 'political transition in Indonesia as a journey to an illiberal type of democracy: namely, oligarchical democracy.' Accordingly, liberal democratisation in Indonesia is failed to overcome the old structure of oligarchs, as 'political contestation remains confined to a competing predatory interests, leading to the marginalisation of civil society forces'. These oligarchical structures, according to him, were not really eliminated by the reformist force in 1998, rather, they reorganise themselves to merge into a democratic atmosphere (Fukuoka, 2013). As the result, the oligarchs can easily perpetuate their patronage linkage and manipulate the electoral system and the liberal democratic arrangement. Hence, if we look at the political dynasties now, it can be ensured that they are always a part of the old oligarchs before democratisation era.

The reorganisation of the old oligarchs, as Fukuoka (2013: 57-58) points out, evokes a lot of scepticism on the ambition of liberal democratisation in Indonesia. Instead of continuously promoting the so-called democratic consolidation by strengthening liberal democraticinstitutions, somescholars, likeHadiz(2003: 592), argue that 'the legacy of authoritarian rule remains important even as the institutional structures of authoritarian regimes unravel.' The existence of the 'democratic form' of the old oligarchs makes liberal democratisation remains problematic. Under their co-optation of resources and accumulation of money, electoral system can never be a fair political battlefield 
for every political actor as there is a latent inequality. This condition is even compounded as the oligarchs are also the embodiment of local predatory markets who take benefit from so-called 'development and modernisation agenda'. As Hadiz points out, 'decentralisation has had little bearing in terms of pushing forward a governance agenda based on transparency and accountability, as neo-institutionalist propose, but has been instrumental in the development of newly decentralised, predatory networks of patronage' (2004a: 699).

This remaining oligarch, which mostly embody as dynastic family, cannot be captured by the single political mechanism of liberal democracy, as their existence keeps maintaining the status quo and neglecting people's participation withinapseudo-democratic system. Seen in this light, therefore, liberal democratic arrangement in Indonesian local context has some difficulties and limitations, considering the nature of Indonesian socio-political context. The accusation of developmental theorist that the emergence of political dynasty is necessarily caused by the lack of economic growth cannot be accepted since the economic development even contributes to accumulate resources and money for the political dynasties itself. Hence, the local oligarchs and dynastic families are often comprised of local capitalists and businessmen as well. In this regard, Hadiz (2001: 146) rightly describes that 'it would not be surprising if business interests, local and national... ...have now diversified by supporting new political vehicles in the hope of establishing new alliances. One recent study concluded that local political elites now largely comprise entrepreneurs who 'matured' under the New Order.'

Secondly, the game of liberal democratic arrangement as 'the only game in town' (Abdulbaki, 2008: 161) is eventually captured by local political elites, especially political dynasty. Considering the nature of oligarchy in our local society, as discussed above, it is difficult to separate the structure of dynastic family with the structure of local liberal democratic institutions. As electoral system becomes the only way to articulate political interest, local people are solely dependent to political elites ruling in the electoral institutions, such as local political party, local representatives, etc. Again, the logic of representation in Schumpeterian model of democracy here is always problematic in terms of people's participation. The electoral system at local level does not only become a political instrument to mediate conflict, but also at the same time becomes a new hegemonic instrument to exclude people's participation. Thus, liberal interpretation of participation here is conceptually degraded as merely an electoral involvement and political gimmick. Hadiz (2003: 593), in this regard, points out that 'the institutions of Indonesia's new democracy have been captured by predatory interest precisely because these were not swept away by the tide of reform.'

Elite capture mentioned above is, of course, contrary to decentralisation's goal, which was promoted by World Bank and international movement after the Cold War ended, that 'a vibrant civil society contributes to good governance and democratisation by ensuring greater public participation in development... ...decentralisation is usually assumed to provide better opportunities for participation by local communities in decision-making' (Hadiz, 2004a: 700). Against this paradox, thus, the developmental theorists' refutations, which solely problematise the weakness of liberal democratic institutions and 'the lack of commitment among political elites' (Hadiz, 2004a: 704), are irrelevant, since electoral system and its derivations, which simply reduce and degrade people's participation, can easily captured by a 'democratic' form of political dynasty. For instance, a research conducted by Hamid (2014: 584) shows how Chosiyah's dynasty dominates some democratic institutions in Banten as shown in the figure 1.

Drawing on the chart, Hamid (2014: 590) argues that, in the context of Banten, family linkage becomes 'the single most important actor that determines the distribution of political power and economic resources at the local level.' It can be clearly seen that Chosiyah's dynastic family dominate in various political institutions, either the local executive or the local representatives. Moreover, this family linkage also spread out among economic cartels and local bossism called jawara (Hamid, 2014: 580-585). That analysis has proven that liberal democratic institutions are again failed to really overcome the tendency of political dynasty at local level.

Accordingly, we ought to rethink the 


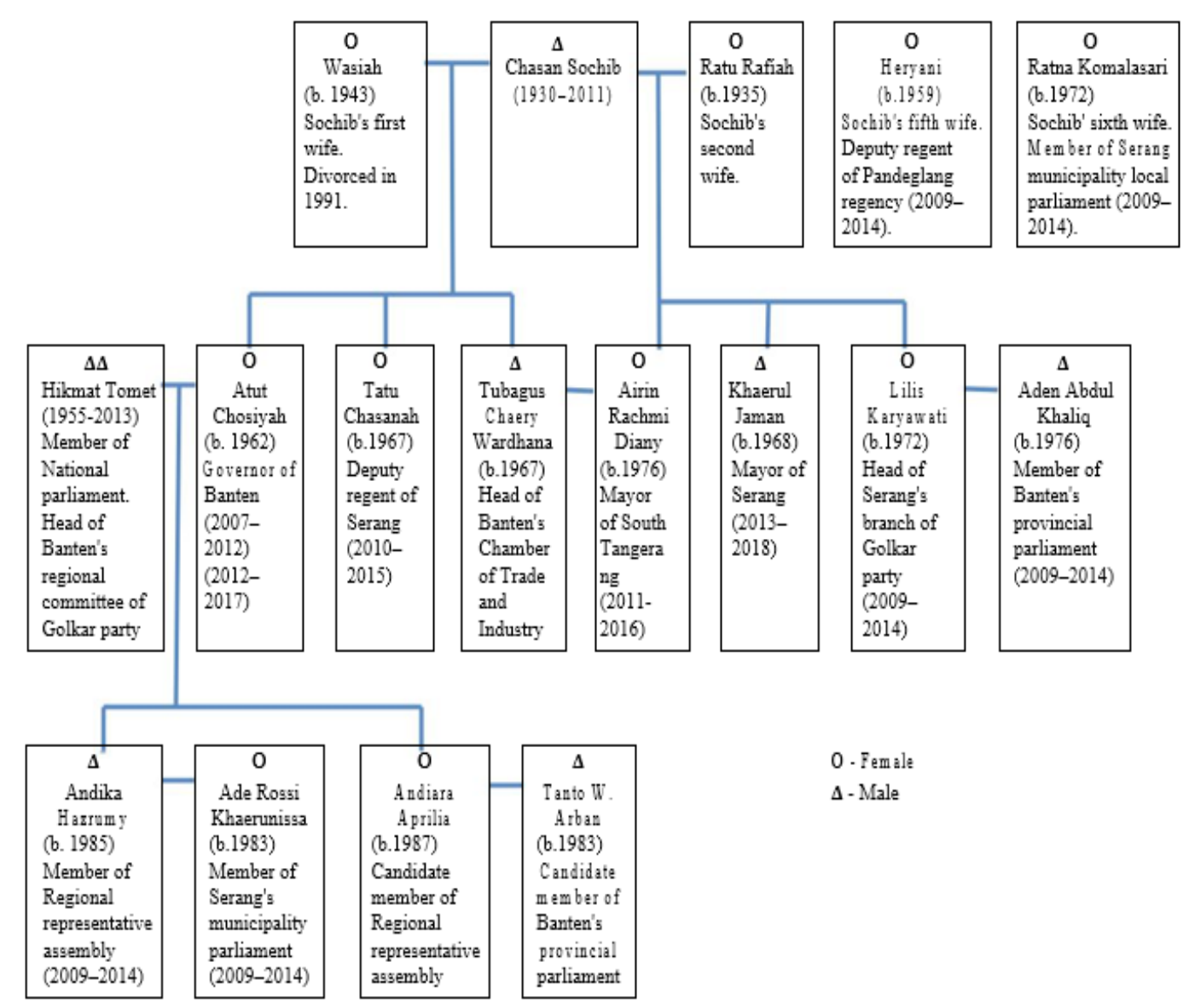

Source: Hamid, 2014: 584

\section{Figure 1. The Dynastic Family of Chasan Shohib in Banten}

idea of decentralisation per se more critically, as people's participation, in terms of political control and involvement in decision-making process, has been neglected. This is in line with Hadiz's argument that:

'...there have been dramatic changes in Indonesia. Electoral politics have become far more important, as have institutions like political parties, the MPR and national and regional parliaments as arenas of political competition... ... But what we are probably seeing is a transition to a system of money-politics in which oligarchic interests, some old and some new, may find means of reconstituting themselves. These developments are partly attributable to the absence of effective organising vehicles representing groups...' (2001: 143).

This deficiency of decentralisation, indeed, gives profit to local oligarchs including political dynasty to capture the electoral system. In line with the discussion in the previous factor, a political dynasty can maximise its accumulated resources to influence voters' choice, and, moreover, force them by using patron-client mechanism and political intimidation (Hadiz, 2004b: 617). As Fukuoka puts in, 'money now plays a crucial role in elections, the electoral process has created 'business bias' which effectively marginalises civil society leaders who may have the potential to become effective politicians but lack of the financial means to contest increasingly expensive elections' (2013: 61).

Thirdly, the last factor that is neglected by liberal democratisation at local level is the context of Indonesian's culture and tradition. Indonesian society, especially at local level, cannot necessarily emerge and adapt the modern form of political system which was derived from Western-centred democracy. Liberal democracy that embodies in local democratic institutions, such as local election, local representatives, and local party, inherently needs liberal values, like individualism and rationalism, in order to create democracy more participative. This kind of need, however, 
contradicts with the nature and empirical reality of Indonesian people, specifically at local level, which are relatively communal, traditional, and collectivist. Accordingly, using Kuhn's theory of 'paradigm research' in criticising liberal interpretation of democratisation in Indonesia, Fukuoka (2011: 99) contends that 'despite its popularity, liberal theory is not congruent with the empirical reality of Indonesia: political transition in Indonesia took place even in the absence of an assertive civil society.'

The incongruity of liberal democracy, therefore, has made some new problem in local democracy. Instead of making local politics more democratic, local democratisation through decentralisation and local election even results and facilitates local predatory oligarchs and political dynasty to dominate and utilise popular vote. Indonesian society's values mentioned before, in some ways, give political profit for political dynasty to perpetuate its domination. As Hamid (2014: 578) points out, 'money politics and 'gangsterism' play a significant role in political change.' The practice of gangsterism here becomes an important issue regarding political dynasties, as they usually use tradition and communal identity to maintain political power, and, moreover, use violence to silence their political opposition (Hamid, 2014: 585). This condition, hence, has led local democracy to the absence of strong civil society.

To sum up, this section basically argues that liberal democratisation is incongruent with the nature and empirical reality of Indonesia. Although local democracy after the policy of decentralisation is successful to make political process institutionally more democratic, it still suffers deficiencies and limitations that have been discussed above. The tendency of political oligarchy frequently abuses the electoral system at local level and utilises it as a political instrument to perpetuate its patrimonialism. Furthermore, the most important issue, this deviation has eventually castrated people's participation in political and decision-making process.

\section{The Establishment of Local Oligarchy And The Absence of Participation}

Indonesian's local democratisation cannot, indeed, be regarded as a new political thing, as it has proceeded for more than a decade. Its implementation, however, still has to face some challenges in order to make local politics more democratic not only institutionally but also substantively. Considering the incongruity of liberal democratisation mentioned before, it is important to rethink Indonesian's local democracy in the future and also envision its prospect in order to overcome the democratic obstacles. In this section, we try to identify some political effects regarding the crisis of participation in local democracy. By doing so, Indonesian democrats hopefully can anticipate these challenges and, eventually, the process of democratisation in Indonesia after 1998 can be relatively better.

Firstly, if we do not take the problem of participatory seriously in Indonesian local democracy, it is not surprising that there will be a tendency of political dynasty and the establishment of new local oligarchs in the larger amount of Indonesian local elections, which can eventually jeopardise common interests. As Tusalem and Pe-Aguirre (2013: 360) explain, 'some scholars argue that the dominance of political dynasty in the political arena has a pernicious effect on public good provision. The underlying logic is that the concentration of power within one family negates accountability to the electorate and deters challenges from the high-quality, reform-oriented candidates.' The embodiment of political dynasty, in some ways, can undermine common interest since it will prioritise its privilege to gain special access to power. As the consequence, there is common interest that will be staked. At the local context, a political dynasty will only focus to maintain and fund its patronage linkage, and, at the same time, neglect and corrupt the others' right outside its political circle.

As the political dynasty has been established, political institutions' performance and public services at local level will automatically decrease. Inspired by the Philippines' experience on political dynasty, Tusalem and Pe-Aguirre (2013: 366) use Mendoza, Beja, Barua, and Venida's analysis to categorise three negative effects regarding public good services:

'First, it prohibits citizens from voicing their demands, needs, and expectations to politicians because a hierarchical culture is manifested that promotes a culture of deference. Second, dynastic families accumulate inordinate amounts of power over time, which may them to violate the rule of law without fear of losing elections 
or facing administrative sanctions from other state authorities. Third, the political selection of leaders emphasises preferential treatment of individuals rather than emphasising meritocracy's level playing field, thus creating a breed of inexperienced politicians who do not have the capacity to govern.'

Hence, the practice of political dynasty essentially ruins the goal of local democratisation itself, as public services will be sacrificed and democratic political circulation will be disturbed. Moreover, the rule of law can be easily trespassed since political dynasty has dominated the political structure. As the result, political institutions have to deal with some incapable and incompetent politicians who has strategic position in deciding public policy and common interest.

Secondly, the consequence that Indonesian local democracy will be facing is the lost of people control. Liberal democratic arrangement in local democracy, as discussed in the previous section, limits the political actor by simply depending on electoral system and representative institutions. Considering the incongruity of the nature of Indonesian democracy, people's participation is substantially reduced and even politically eliminated from decision-making process. Moreover, this institutional catastrophe is compounded as civil society at local level is traditionally weakened and structurally oppressed by violence conducted by political oligarchs. As Tusalem and Pe-Aguirre (2013: 366) note, 'political families develop linkages with clients who have been and will be loyal in each and every electoral cycle.'

Against the political landscape above, therefore, the true participation, as envisaged by Pateman and Hirst, in local democracy can never be reached within the narrow and limited liberal democratisation. How can we regard local democracy to be democratic if the demos at local cannot really participate in political process? How can we regard development and modernisation agenda to be successful in terms of improving people's participation if local democracy is eventually captured by political elites and dynasty? The problem of participation can lead to the nomination of an unqualified political leader and biased public policy. In the long term, it also can lead local democracy to the crisis of leadership, as Hadiz (2004a: 705) argues that 'neo-liberal agenda is not going to be driven by a progressive civil society, but must be enforced by technocratic and managerial interests constructed within the state bureaucracy.'

Thirdly, local democracy, at the end of the day, becomes prone to corruption. Some cases of corruption which afflicted local Indonesian politicians have shown that the practice of political dynasty is strongly related to corruptive and abusive action. According to Banten's experience, as presented by Hamid (2014: 580), there are some dynastic family members who officiate as the head of Indonesian Chamber of Commerce and Industry (Kamar Dagang dan industri Indonesia or KADIN) and Banten branch of Indonesian Association of Construction Companies (Gabungan Pelaksana Konstruksi Nasional Indonesia Cabang Banten or GAPENSI). By such position, Chosiyah's father dynasty can obtain several government's projects, and 'through group of violence he fostered and deepened business lobbying for government construction projects' (Hidayat, 2007, in Hamid, 2014: 580). This makes a complicated intersection of interest as the ruling dynasty is comprised of kinship interest that embodied in political institutions and also business interest at the same time. We can also see the same corruptive tendency in another political dynasty, such as in Cimahi and Klaten.

Broadly speaking, the consequences of political dynasty have been now identified and they arguably have negative implications for the future of Indonesian local democracy. In the light of participatory democracy, thus, the proceeding liberal democratisation at local level is not completely successful to accommodate people's participation and, rather, it can be used by political dynasty and local oligarchs to perpetuate their domination over the people. If Indonesian democrats do not seriously reformulate the political arrangement to be more participative, this kind of tendency will easily spread throughout Indonesian local elections. As the result, the worst condition that probably Indonesian local democracy has to face is the absence of people's participation, which can lead to either kleptocracy or anarchism.

\section{CONCLUSION}

To conclude, this article tries to discuss the cause of political dynasty in Indonesian local 
politics by using participatory point of view and criticising the narrow liberal democratisation agenda. We have shown in the discussion in this article that although liberal democratisation is successful in making local politics institutionally more democratic, it still suffers a lot of deficiencies and limitations especially in terms of accommodating participation at local level. Accordingly, the idea of modernisation and development theory has been proven to fail as local oligarchs that embody as political dynasty eventually capture the decision-making process. This failure, as we have argued, is caused by the incongruity of Western-centred liberal democracy with the nature and empirical reality of Indonesian local politics, which makes it cannot be necessarily adopted.

Therefore, we need to reformulate our local democracy to be more participatory in order to eradicate the oligarchical structures and the widespread corruption at the local level. In this regard, some participative variants of democracy have been introduced and examined to complement the limitation of liberal democratisation, for example, the emergence of village democracy after the Village Act was ratified in 2014. Moreover, we ought to strengthen and organise progressive civil society to really participate in the political and decisionmaking process, so every dynastic potential can be easily eliminated.

\section{REFERENCES}

Abdulbaki, L. (2008). Democratisation in Indonesia: From Transition to Consolidation. Asian Journal of Political Science, 16:2, 151-172, DOI: 10.1080/02185370802204099

Artharini, I. (2017). Kasus suap bupati Klaten: Ada kaitan dinasti politik dan korupsi? (The bribery case of Klaten regent: Is there relation between political dynasty and corruption?). BBC Indonesia, accessed online on $6^{\text {th }}$ of February 2017. URL: http://www.bbc.com/indonesia/ indonesia-38484498

Fukuoka, Y. (2011). Political change in Indonesia. Annual International Conference on Political Science, Sociology and International Relations (PSSIR 2011), p. 95-100.
(2013). Oligarchy and Democracy in Post-Soeharto Indonesia. Political Studies Review, Vol. 11, p. 52-64, DOI: 10.1111/j.1478-9302.2012.00286.x

Hadiz, V. R. (2001). Capitalism, oligarchic power and the state in Indonesia. Historical Materialism, Vol. 8, Issue 1, p. 119-151.

(2003). Reorganising political power in Indonesia: A consideration of so called 'democratic transition'. The Pacific Review, 16:4, p. 591-611, DOI: 10.1080/0951274032000132272

(2004a). Decentralization and democracy in Indonesia: A critique of neo-institutionalist perspectives. Development and Change 35(4), p. 697-718.

(2004b). Indonesian local party politics. Critical Asian Studies, 36:4, p. 615-636, DOI: 10.1080/1467271042000273275

Hamid, A. (2014). A family matter: Political corruption in Banten, Indonesia. Asian Politics \& Policy, Vol. 6, Number 4, p. 577-593.

Hirst, P. (1988). Associational socialism in a pluralist state. Journal of Law and Society, Vol. 15, No. 1, Law, Democracy, 7 Social Justice, p. 139150.

Pateman, C. (2014 [1970]). Participation and democratic theory. Cambridge: Cambridge University Press.

Peou, S. (2014). The Limits and Potential of Liberal Democratisation in Southeast Asia. Journal of Current Southeast Asia Affairs, 33, 3, pp. 19-47.

Sawitri, A. A. (2016). Ketua KPK Minta Publik Waspadai Korupsi Dinasti Politik(Head of KPK to ask public to be aware of dynastic political corruption). Tempo.co, accessed online on $6^{\text {th }}$ of February 2017. URL: https://m.tempo. co/read/news/2016/12/03/063825091/ ketua-kpk-minta-publik-waspadaikorupsi-dinasti-politik

Tadjoeddin, M. Z. (2012). Electoral conflict and the maturity of local democracy in 
Indonesia: testing the modernisation hypothesis. Journal of the Asia Pacific Economy, Vol. 17, No 3, p. 476-497.

Trajano, J. C. I., and Yoes, C. K. (2013). Indonesia and the Philippines: Political dynasties in democratic state. RSIS Commentaries, No. 018. Singapore: Nanyang Technological University.
Tusalem, R. F., and Pe-Aguirre, J. J. (2013). The effects of political dynasties on effective democratic governance. Asian Politics \& Policy, Volume 5, Number 3, p. 359-386. 